\title{
Factors associated with vulnerability and fragility in the elderly: a cross-sectional study
}

\author{
Fatores associados à vulnerabilidade e fragilidade em idosos: estudo transversal \\ Factores relacionados a la vulnerabilidad y fragilidad en ancianos: estudio transversal
}

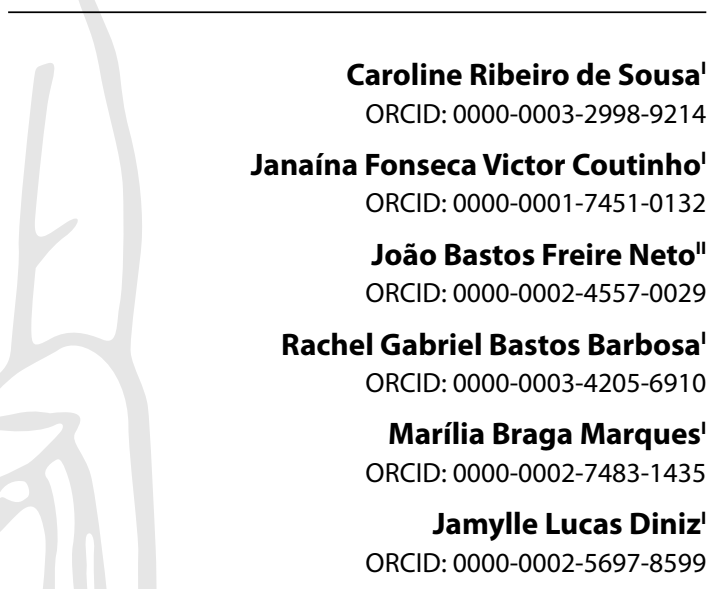

'Universidade Federal do Ceará. Fortaleza, Ceará. Brazil. "Secretaria Municipal de Saúde de Fortaleza. Fortaleza, Ceará. Brazil.

How to cite this article: Sousa CR, Coutinho JFV, Freire Neto JB, Barbosa RGB, Marques MB, Diniz JL. Factors associated with vulnerability and fragility in the elderly: a cross-sectional study. Rev Bras Enferm. 2022;75(2):e20200399. https://doi.org/10.1590/0034-7167-2020-0399

Corresponding author:

Caroline Ribeiro de Sousa

E-mail: carolineribeiro7@hotmail.com

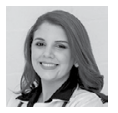

EDITOR IN CHIEF: Dulce Barbosa ASSOCIATE EDITOR: Marcia Magro

Submission: 07-09-2020 Approval: 05-27-2021

\begin{abstract}
Objectives: to assess factors associated with vulnerability and fragility in the elderly. Methods: crosssectional study with 384 elderly people in Fortaleza, Ceará. The Vulnerable Elders Survey and Clinical-Functional Vulnerability Index - 20 were used. Chi-square and Fisher's exact tests were used for associations. In the analysis of the combined influence of risk factors, the stepwise logistic regression and multinomial regression methods were adopted. Results: 251 (65.4\%) non-vulnerable and 133 (34.6\%) vulnerable elders. From the vulnerable elders analyzed, 42 (30.9\%) are at high risk for frailty. Factors associated with vulnerability: age, gender, presence of comorbidities, hypertension, diabetes, osteoporosis and use of polypharmacy. There is a $30 \%$ increase in the chance of vulnerability for each additional drug. Physical activity reduces the chance of vulnerability by $60 \%$. Factors associated with frailty: educational level; self-perception of health; comorbidities; polypharmacy. Conclusions: it is important to pay attention to the presence of arterial hypertension, osteoporosis, polypharmacy, and encourage the practice of physical activity.
\end{abstract}

Descriptors: Vulnerability Study; Fragility; Aged; Primary Health Care; Nursing.

\section{RESUMO}

Objetivos: avaliar fatores associados à vulnerabilidade e fragilidade em idosos. Método: estudo transversal, com 384 idosos em Fortaleza, estado do Ceará. Utilizou-se o Vulnerable Elders Survey e Índice de Vulnerabilidade Clínico-Funcional - 20. Empregaram-se testes qui-quadrado e exato de Fisher para associações. Na análise da influência conjunta dos fatores de risco, adotou-se o método de regressão logística stepwise e multinomial stepwise. Resultados: $251(65,4 \%)$ não vulneráveis e 133 (34,6\%) vulneráveis. Dos vulneráveis analisados, 42 (30,9\%) têm alto risco para fragilidade. Fatores associados à vulnerabilidade: idade, sexo, presença de comorbidades, hipertensão, diabetes, osteoporose e uso de polifarmácia. Há aumento de $30 \%$ na chance de vulnerabilidade para cada medicamento adicional. A atividade física reduz em $60 \%$ a chance de vulnerabilidade. Fatores associados à fragilidade: escolaridade; autopercepção de saúde; comorbidades; polifarmácia. Conclusões: atentar-se para a presença em idosos de hipertensão arterial, osteoporose, polifarmácia e incentivar a prática de atividade física.

Descritores: Vulnerabilidade em Saúde; Fragilidade; Idoso; Atenção Primária à Saúde; Enfermagem.

\section{RESUMEN}

Objetivos: evaluar factores relacionados a vulnerabilidad y fragilidad en ancianos. Métodos: estudio transversal, con 384 ancianos en Fortaleza, Ceará. Utilizó el Vulnerable Elders Survey e Índice de Vulnerabilidad Clínico-Funcional - 20. Emplearon testes chi-cuadrado y exacto de Fisher para relaciones. En el análisis de la influencia conjunta de los factores de riesgo, adoptó el método de regresión logística stepwise y multinomial stepwise. Resultados: $251(65,4 \%)$ no vulnerables y $133(34,6 \%)$ vulnerables. De los vulnerables analizados, $42(30,9 \%)$ hay alto riesgo para fragilidad. Factores relacionados a vulnerabilidad: edad, sexo, presencia de comorbilidades, hipertensión, diabetes, osteoporosis y uso de polifarmacia. Hay aumento de $30 \%$ en la chance de vulnerabilidad para cada medicamento adicional. La actividad física reduce en $60 \%$ la chance de vulnerabilidad. Factores relacionados a la fragilidad: escolaridad; autopercepción de salud; comorbilidades; polifarmacia. Conclusiones: Atentarse para la presencia en ancianos de hipertensión arterial, osteoporosis, polifarmacia e incentivar la práctica de actividad física. Descriptores: Vulnerabilidad en Salud; Fragilidad; Anciano; Atención Primaria de Salud; Enfermería. 


\section{INTRODUCTION}

Aging leads to the development of vulnerability and fragility. Vulnerability derives from the Latin vulnerare, which means "the possibility of being hurt"; it has a biological, socioeconomic, and psychosocial nature. Frailty, on the other hand, is characterized as a multifactorial syndrome, which involves dysregulation of the neuroendocrine system and immune system dysfunction, resulting in weight loss, muscle weakness, low resistance, decreased mobility speed and a reduced level of physical activity ${ }^{(1-2)}$.

Vulnerability can induce frailty in the elderly. Thus, it is understood that every frail elderly person is vulnerable. However there are elderly people in a vulnerable situation who are not frail. It is estimated that $10 \%$ to $25 \%$ of the population over 65 years of age is in a fragile situation; and, for people aged 85 or over, $45 \%{ }^{(3-4)}$.

Vulnerability and fragility increase the prevalence of pathologies and disabilities, in addition to being burdens for the family and raising the costs of health services. This results in complex demands that require specific care, involving the elderly, families, communities, health professionals, and managers ${ }^{(5-6)}$.

The assessment of elderly people in terms of vulnerability and fragility is recommended by international and national organizations, as it makes it possible to identify the biological, physical, cognitive and psychological determinants related to these conditions and, thus, to promote appropriate measures ${ }^{(7)}$.

There are studies about vulnerability and fragility, but most of them do not analyze the factors associated with each condition independently ${ }^{(8-11)}$. Thus, studies capable of tracking vulnerable elderly people, identifying the frail elderly and evaluating the associated aspects in each condition are needed. Investigations of this nature are relevant, as they facilitate the implementation of measures aimed at identifying and monitoring both vulnerable and frail elderly people, in order to promote functionality, independence, good lifestyle habits, and reduce functional decline ${ }^{(5-6)}$.

\section{OBJECTIVES}

To evaluate the factors associated with vulnerability and fragility in the elderly.

\section{METHODS}

\section{Ethical aspects}

This research was developed in accordance with Resolution $466 / 2012$ by the National Health Council and was approved by the Research Ethics Committee of the Federal University of Ceará.

\section{Design, study location and period}

Cross-sectional observational study, following the guidelines of the EQUATOR network, using the instrument Strengthening the Reporting of Observational Studies in Epidemiology (STROBE)

(12). It was carried out from May 2018 to June 2019, in five Primary Health Care Units (UAPS) in Fortaleza, in the state of Ceará.

\section{Population or sample; inclusion and exclusion criteria}

To calculate the sample, a cross-sectional study formula with an infinite population was used, resulting in 384 elderly people registered at the UAPS in Fortaleza.

Inclusion criteria were individuals over 60 years old attended at the UAPS. The following were excluded: elderly people who, after a cognitive assessment performed through the Mini-Mental State Examination (MMSE), had a score lower than 13 for illiterate seniors and a score lower than 17 for literate ones ${ }^{(13)}$; and elderly people with a confirmed diagnosis of dementia, regardless of the type. Cognitively compromised elderly people were excluded to eliminate information bias. 435 elderly people were enrolled; 30 were excluded for not reaching the score determined on the MMSE, 5 for having a confirmed diagnosis of Alzheimer's, and 25 for not completing the instruments. In the end, the study had 384 participants.

\section{Study protocol}

Data collection was carried out through an interview, lasting 20 minutes. The elders were approached while waiting for care at the units. The instruments were completed by the researchers, and the collection took place in three stages: collection of sociodemographic, clinical, and anthropometric data; vulnerability assessment; and assessment of the frailty of vulnerable elderly people.

The sociodemographic variables collected were gender, age, educational level, marital status, and race. The clinical variables were self-reported comorbidities, medications in use and physical exercise. Anthropometric variables were weight, height, body mass index and calf circumference.

Vulnerability assessment was performed using the Vulnerable Elders Survey (VES-13), developed to identify vulnerable elderly people living in the community. The VES-13 was translated and adapted for Brazil and proved to be a reliable instrument regarding the stability and internal consistency of its measurements ${ }^{(14)}$. It consists of four items: age, self-perception of health, physical limitations, and disabilities, which are evaluated in 13 questions. The survey classifies vulnerability as such: elders with a score between 0 and 2 are not considered vulnerable, so they can be followed up in the Primary Health Care Units (UAPS), without any related intervention; when the score is equal to or greater than 3 , the elder must be evaluated more specifically, since they have a 4.2 times greater risk of functional decline ${ }^{(14)}$.

Regarding frailty, the Clinical-Functional Vulnerability Index - 20 (IVCF20) was used, which addresses multidimensional characteristics of the elderly, consisting of 20 questions distributed in the following eight domains: age, self-perception of health, activities of daily living, cognition, mood/behavior, mobility, communication, and presence of multiple comorbidities ${ }^{(15)}$.

The classification of the clinical and functional condition of the elderly is found through the following criteria: with a score from 0 to 6, the elderly person is considered robust and can be monitored by Primary Health Care; with a score from 7 to 14, the elderly person is considered at risk of frailty, being referred to an intermediate multidimensional assessment to be carried out in 
Primary Health Care; and with a score equal to or above 15 points, the elderly person is considered to be in a fragile condition, and must be assisted in Secondary Care with preventive, curative or palliative follow-up ${ }^{(15)}$.

\section{Analysis of results and statistics}

Data were grouped and statistically analyzed using the Statistical Package for Social Sciences program (version 22.0). Descriptive statistical analysis was performed. The chi-squared and Fisher's exact tests were used to assess the association between the outcome variables (vulnerability and frailty) and the independent variables. The significance level adopted was $5 \%(p<0.05)$.

In the analysis of the joint influence of risk factors for vulnerability, the stepwise logistic regression method was used, in which the Wald test was applied to identify the variables to compose the model. An omnibus test was carried out to globally fit the model, and the Hosmer-Lemeshow test was used to compare the frequencies observed in the sample and those expected when applying the logistic model found. In addition, the Nagelkerke $\mathrm{R}^{2}$ was calculated to measure the global vulnerability determination capability.

As for frailty, the stepwise multinomial logistic regression method was used, in which the Wald test was applied to identify the variables that compose the model; the likelihood ratio test was used for the global fit of the model; and the Pearson's chisquare test for adjustment, to compare the frequencies observed in the sample with those expected when applying the logistic model found. Furthermore, Nagelkerke's $\mathrm{R}^{2}$ was also calculated to measure the ability to determine global frailty, based on the variables included in the final model.

\section{RESULTS}

The mean age of the 384 elders was 70.2 years $( \pm 7.32)$; and their mean years of formal education studying were $6.52( \pm 4.54)$. Most were female, 264 (67.4\%); 126 were married (32.8\%), 205 (53.4\%) did not practice physical activity, 333 (86.7\%) had some comorbidity, and 94 (24.5\%) used five or more medications daily. Their mean weight was $66.6 \mathrm{~kg}( \pm 27.40)$ mean height 1.56 $\mathrm{m}( \pm 8.37)$; mean body mass index $26.08 \mathrm{~kg} / \mathrm{cm}$; and mean calf circumference $34.64 \mathrm{~cm}( \pm 3.56)$.

In the assessment of vulnerability, individuals over 85 years (3.1\%) stood out for being already considered vulnerable (100\%), with an association between age and vulnerability $(p<0.001)$. The older the participant, the greater the chance that the individual is vulnerable.

Regarding self-perception of health, from the 185 who reported their health as regular, 85 (45.9\%) were vulnerable, and from the $39(10.20 \%)$ who reported it as bad, 19 (48.7\%) were vulnerable. Although 27 (7\%) elderly people considered their health to be excellent, $3(11.1 \%)$ were rated as vulnerable. A negative selfperception of health is related to vulnerability $(p<0.001)$.

In the domain of physical limitations, of the 133 vulnerable, 85 (69.9\%) had more difficulty in "Bending, squatting or kneeling", followed by 78 (58.6\%) who had difficulty"Lifting or carrying objects weighing approximately 5 kg" and 57 (50.7\%) who had difficulty "Doing heavy housework such as mopping the floor". Regarding vulnerability, there was a significant association in these three activities ( $p<0.001$ ), with the activity of "Bending, squatting or kneeling" having the largest number of vulnerable elderly (85 of the elderly reported having a lot of difficulty or to be incapable).

In "Doing heavy housework such as mopping the floor", the 67 $(51.5 \%)$ who responded that they had a lot of difficulty or were unable to do it were vulnerable. In "Lifting or carrying objects weighing approximately $5 \mathrm{~kg}$ ", from the 99 who answered having a lot of difficulty or being unable to do so, 78 (78.8\%) were vulnerable. It was evident that a greater difficulty in activities that required strength and physical effort was associated with vulnerability.

Regarding disabilities, 61 (15.9\%) had more difficulty in making their personal purchases, with 58 (95.1\%) considered vulnerable. $35(9.4 \%)$ had no autonomy over their money, from which 32 (91.4\%) were vulnerable.

Of the total, 133 elderly (34.6\%) were classified as vulnerable and 251 (65.4\%) as non-vulnerable. Table 1 shows the sociodemographic and clinical variables associated with vulnerability.

There was an association of vulnerability with age $(p=0.001)$, gender $(p=0.010)$, educational level $(p=0.008)$, marital status $(p=0.004)$, skin color $(p=0.003)$, physical activity $(p=0.002)$, presence of comorbidities $(p=0.007)$, having hypertension ( $p=$ $0.001)$, diabetes $(p=0.001)$, osteoarthritis $(p=0.008)$, osteoporosis $(p=0.003)$ and using polypharmacy $(p=0.001)$.

The association between body mass index and vulnerability revealed that $52(39.1 \%)$ of the vulnerable elders had an appropriate weight, while 34 (25.6\%) were obese, 35 (26.3\%) were underweight, and 12 (9\%) were overweight. Furthermore, there was a significant association between calf circumference and vulnerability $(p=0.010)$, in which $108(81.2 \%)$ individuals had an adequate circumference, while 25 (18.8\%) had a circumference below $31 \mathrm{~cm}$.

Table 2 shows that five variables are related to the occurrence of vulnerability among the elderly.

It was identified that vulnerability grows among the elderly and among those who do not engage in physical activity, increasing the chance of presenting vulnerability for each year of age by $7 \%$. Furthermore, it was found that the probability of being vulnerable increases by more than twice if the elderly person presents arterial hypertension and osteoporosis. In addition, there is a $30 \%$ increase in the chance of vulnerability for each additional medication used. On the other hand, performing physical activity reduces by almost $60 \%$ the chance of an elderly person being classified as vulnerable.

After stratifying the elderly into vulnerable and non-vulnerable, the frailty of 133 vulnerable elders was evaluated, from which 38 (10.2\%) had low risk, classified as robust elders; 56 (41\%) were at moderate risk, classified as at risk of frailty; and 42 (30.9\%) showed high risk, classified as frail elders.

Considering the domains of the IVCF-20, 38 (29.3\%) were between 75 and 84 years old, and 12 (8.3\%) were 85 years old or more. Regarding self-rated health, 104 (78.2\%) considered their health to be fair or poor. In Activities of Daily Living, 48 (36.1\%) stopped doing the groceries because of their health. Regarding cognition, 70 (52.6\%) reported that a family member said they were forgetful. In the mood domain, 87 (65.4\%) reported being sad and discouraged. In the mobility domain, 34 (25.6\%) reported 
some difficulty in walking that interferes with daily activities, 42 (31.6\%) had two or more falls in the last year, 47 (35.3\%) reported reduction of urine or feces. Regarding communication, there was a prevalence of elderly people (54.1\%) with changes in vision that hinder daily activities. More than half, 67 (50.4\%), responded they do have multiple comorbidities. The most prevalent condition was the regular use of five or more medications (44.4\%), followed by hospitalizations in the last six months (7.5\%) and having five or more chronic diseases (4.5\%).

There was an association of the IVCF-20 domains with the risk of frailty in the elders who have clinical-functional vulnerability (Table 3).

The domain in which the elderly at risk of frailty scored the most was self-perceived health, while the domain in which the frail elderly scored the most was multiple comorbidities. There was an association in the following domains: self-perceived health $(p=0.018)$, Activities of Daily Living ( $p<0.001)$, cognition $(p<$ $0.001)$, mood $(p=0.001)$ and multiple comorbidities $(p<0.001)$.

Table 4 shows the multinomial regression analysis of risk factors for frailties in vulnerable elderly people, according to the domains of the IVCF-20.

The chance of presenting a moderate to high risk of frailty is lower among those younger, with a reduction of around $99 \%$ for each year of age. A self-perceived poor health increases the moderate and high risk of frailty.

The ability to develop Activities of Daily Living was statistically related to a reduction in the moderate or high risk of frailty among the elderly. Similarly, mobility capacity and the absence of multiple morbidities were associated with a reduction in the chance of being classified as moderate or high risk of frailty. On the other hand, the absence of cognitive or mood problems was only associated with a reduction in the high risk of frailty. These two variables showed no difference in risk between elderly people with low or moderate risk of frailty. The communication domain is not shown in Table 4, as it did not influence the three levels of risk of frailty among the elderly.

The sociodemographic and clinical factors associated with clinical-functional vulnerability regarding the risk of frailty were verified, as shown in Table 5.

In terms of education, there was a significant association ( $p$ $=0.008$ ) according to which most illiterate people were at risk of becoming frail (45.5\%) or were frail (31.8\%). As for the clinical variables in relation to the practice of physical activity, there was an important association ( $p=0.063$ ), as the non-practice of physical exercise can influence the development of frailty, since most elderly people were at risk of frailty (44.9\%) or were frail elderly (33.7\%).

The presence of comorbidities was relevant regarding the development of clinical-functional vulnerability, with a significant association ( $p=0.020)$, as $40.8 \%$ and $33.1 \%$ of the elderly evaluated were at risk of frailty or were frail, respectively. As for the elderly at risk, there was a higher prevalence of hypertensive patients (42.1\%), patients with osteoarthritis (47.7\%) and osteoporosis (44.7\%). In frail individuals, there was a higher prevalence of elderly people with depression (66.7\%) and diabetes (38.7\%). Another factor for clinical-functional vulnerability is polypharmacy $(p=0.001)$, which also increases the tendency of individuals to develop fragility (53.3\%).
Table 1 - Sociodemographic and clinical factors associated with the vulnerability of the elderly assisted in the Primary Health Care Units, Fortaleza, Ceará, Brazil, 2019 ( $\mathrm{N}=384$ elderly)

\begin{tabular}{|c|c|c|c|}
\hline \multirow{2}{*}{ Variable } & \multicolumn{2}{|c|}{ Vulnerability } & \multirow{2}{*}{$p$ value } \\
\hline & Non-vulnerable & Vulnerable & \\
\hline Age & & & $0.001 *$ \\
\hline $60-79$ & $234(69.6 \%)$ & 102 (30.4\%) & \\
\hline $80-100$ & 17 (35.4\%) & $31(64.6 \%)$ & \\
\hline Gender & & & $0.010^{*}$ \\
\hline Female & $158(61 \%)$ & $101(39 \%)$ & \\
\hline Male & $93(74.4 \%)$ & $32(25.6 \%)$ & \\
\hline Educational level & & & $0.008^{*}$ \\
\hline More than 6 years & 122 (69.7\%) & $53(30.3 \%)$ & \\
\hline 1 to 5 years & $112(65.9 \%)$ & $58(34.1 \%)$ & \\
\hline Illiterate & $17(43.6 \%)$ & $22(56.4 \%)$ & \\
\hline Marital status & & & $0.004^{*}$ \\
\hline Married & $82(65.1 \%)$ & $44(34.9 \%)$ & \\
\hline Single & $69(78.4 \%)$ & $19(21.6 \%)$ & \\
\hline Widow & $58(55.8 \%)$ & $46(44.2 \%)$ & \\
\hline Divorced & $40(67.8 \%)$ & $19(32.2 \%)$ & \\
\hline Stable union & $2(28.6 \%)$ & $5(71.4 \%)$ & \\
\hline Skin color & & & $0.003^{*}$ \\
\hline White & $70(77.8 \%)$ & $20(22.2 \%)$ & \\
\hline Brown & $139(64.1 \%)$ & $78(35.9 \%)$ & \\
\hline Indigenous & 0 & $2(100 \%)$ & \\
\hline Black & $39(54.2 \%)$ & $33(45.8 \%)$ & \\
\hline Yellow & $3(100 \%)$ & 0 & \\
\hline Physical activity & & & $0.002^{*}$ \\
\hline Yes & $132(73.7 \%)$ & $47(26.3 \%)$ & \\
\hline No & $119(58.0 \%)$ & $86(42 \%)$ & \\
\hline Comorbidities & & & $0.007^{*}$ \\
\hline Yes & $209(62.8 \%)$ & $124(37.2 \%)$ & \\
\hline No & $42(82.4 \%)$ & $9(17.6 \%)$ & \\
\hline Hypertension & & & $0.001 *$ \\
\hline Yes & $140(56.2 \%)$ & 109 (43.8\%) & \\
\hline No & $111(82.2 \%)$ & 24 (17.8\%) & \\
\hline Diabetes & & & $0.001^{*}$ \\
\hline Yes & $82(53.6 \%)$ & $71(46.4 \%)$ & \\
\hline No & $169(73.2 \%)$ & $62(26.8 \%)$ & \\
\hline Osteoarthritis & & & $0.008^{*}$ \\
\hline Yes & $48(53.3 \%)$ & $42(46.7 \%)$ & \\
\hline No & $203(69 \%)$ & 91 (31\%) & \\
\hline Osteoporosis & & & $0.003^{*}$ \\
\hline Yes & $50(69.6 \%)$ & 45 (47.4\%) & \\
\hline No & 201 (52.6\%) & $88(30.4 \%)$ & \\
\hline Medications & & & $0.001^{*}$ \\
\hline $0-4$ & $216(74.5 \%)$ & $74(25.5 \%)$ & \\
\hline 5 or more & 35 (37.2\%) & $59(62.8 \%)$ & \\
\hline Physical activity & & & $0.002^{*}$ \\
\hline Yes & 132 (73.7\%) & $47(26.3 \%)$ & \\
\hline No & $119(58.0 \%)$ & $86(42 \%)$ & \\
\hline
\end{tabular}

${ }^{*}$ Chi-square and Fisher's exact test, considering $p<0.05$.

Table 2 - Logistic regression model for predictor variables of vulnerability in elderly patients assisted in Primary Health Care Units, Fortaleza, Ceará, Brazil, $2019(\mathrm{~N}=384)$

\begin{tabular}{|c|c|c|c|c|c|c|c|}
\hline Variables & B & Wald & gl & Sig. & OR & \multicolumn{2}{|c|}{ Cl95\% for OR } \\
\hline Age & 0.069 & 15.93 & 1 & $<0.001$ & 1.07 & 1.04 & 1.11 \\
\hline Physical activity & -0.857 & 11.76 & 1 & 0.001 & 0.42 & 0.26 & 0.69 \\
\hline Hypertension & 0.832 & 7.70 & 1 & 0.006 & 2.30 & 1.28 & 4.13 \\
\hline Osteoporosis & 0.711 & 6.57 & 1 & 0.010 & 2.04 & 1.18 & 3.51 \\
\hline Medication & 0.271 & 20.51 & 1 & $<0.001$ & 1.31 & 1.17 & 1.47 \\
\hline \multicolumn{8}{|c|}{ Model adjustment: } \\
\hline \multicolumn{2}{|c|}{$\begin{array}{l}\text { Omnibus test: } \\
X^{2}=92.2 ; g l=5 ; p<0.001\end{array}$} & \multicolumn{4}{|c|}{$\begin{array}{l}\text { Hosmer-Lemeshow: } \\
x^{2}=2.90 ; g l=8 ; p=0.941\end{array}$} & \multicolumn{2}{|c|}{$R^{2}=0.295$} \\
\hline
\end{tabular}


Table 3 - Association of the domains of the Clinical-Functional Vulnerability Index - 20, in relation with the risk of frailty of vulnerable elderly people cared for in the Primary Health Care Units, Fortaleza, Ceará, Brazil, $2019(n=133)$

\begin{tabular}{|c|c|c|c|c|}
\hline \multirow[t]{2}{*}{ Domain } & \multicolumn{3}{|c|}{$\begin{array}{c}\text { Clinical-Functional } \\
\text { Vulnerability Index - } 20\end{array}$} & \multirow[t]{2}{*}{$p$ value } \\
\hline & Robust & Frailty risk & Frail & \\
\hline Age & & & & 0.143 \\
\hline Did not score & $22(26.5 \%)$ & $29(34.9 \%)$ & $32(38.6 \%)$ & \\
\hline Scored & $13(28.2 \%)$ & $27(51.3 \%)$ & $10(20.5 \%)$ & \\
\hline Self-Perception of Health & & & & $0.018^{*}$ \\
\hline Did not score & $24(23.1 \%)$ & $41(39.4 \%)$ & $39(37.5 \%)$ & \\
\hline Scored & $11(37.9 \%)$ & $15(51.7 \%)$ & $3(10.3 \%)$ & \\
\hline Daily Living Activities & & & & $<0.001^{*}$ \\
\hline Did not score & $27(42.2 \%)$ & $30(46.9 \%)$ & $7(10.9 \%)$ & \\
\hline Scored & $8(11.8 \%)$ & $25(36.8 \%)$ & $35(51.5 \%)$ & \\
\hline Cognition & & & & $<0.001^{*}$ \\
\hline Did not score & $22(43.1 \%)$ & $21(41.2 \%)$ & $8(15.7 \%)$ & \\
\hline Scored & $13(16 \%)$ & $34(42 \%)$ & $34(42 \%)$ & \\
\hline Mood & & & & $0.001^{*}$ \\
\hline Did not score & $20(48.8 \%)$ & $15(36.6 \%)$ & $6(14.6 \%)$ & \\
\hline Scored & $15(16.7 \%)$ & $39(43.3 \%)$ & $36(40 \%)$ & \\
\hline Mobility & & & & $<0.001^{*}$ \\
\hline Did not score & $23(67.7 \%)$ & $9(26.5 \%)$ & $2(5.9 \%)$ & \\
\hline Scored & $12(12.1 \%)$ & $47(47.5 \%)$ & $40(40.4 \%)$ & \\
\hline Communication & & & & 0.106 \\
\hline Did not score & $13(27.1 \%)$ & $25(52.1 \%)$ & $10(20.8 \%)$ & \\
\hline Scored & $22(26.5 \%)$ & $30(36.1 \%)$ & $31(37.3 \%)$ & \\
\hline Multiple comorbidities & & & & $<0.001 *$ \\
\hline Did not score & $28(43.1 \%)$ & $32(34.8 \%)$ & $5(77 \%)$ & \\
\hline Scored & $7(10.6 \%)$ & 23 (34.8\%) & $36(54.4 \%)$ & \\
\hline
\end{tabular}

Table 4 - Multinomial logistic regression model for predictor variables of the risk of frailty among vulnerable elderly people cared for in Primary Health Care Units, Fortaleza, Ceará Brazil, $2019(n=133)$

\begin{tabular}{|c|c|c|c|c|c|c|c|}
\hline \multirow[b]{2}{*}{ Moderate risk } & \multirow[t]{2}{*}{ B } & \multirow[t]{2}{*}{ Wald } & \multirow[t]{3}{*}{ df } & \multirow[t]{2}{*}{ Sig. } & \multirow[t]{2}{*}{$\operatorname{Exp}(B)$} & \multicolumn{2}{|c|}{$\mathrm{Cl} 95 \%$} \\
\hline \multirow{2}{*}{\multicolumn{7}{|c|}{ Age }} & \\
\hline & & & & & & & \\
\hline Did not score & -4.19 & 6.28 & 1 & 0.012 & 0.015 & 0.001 & 0.401 \\
\hline Scored & -3.99 & 5.12 & 1 & 0.024 & 0.018 & 0.001 & 0.586 \\
\hline \multicolumn{8}{|l|}{ Self-Perception of Health } \\
\hline Poor (scored) & 5.80 & 6.10 & 1 & 0.014 & 329.4 & 3.306 & 32810.9 \\
\hline Regular (scored) & 4.67 & 5.78 & 1 & 0.016 & 107.1 & 2.369 & 4845.1 \\
\hline Good (did not scored) & 4.33 & 4.60 & 1 & 0.032 & 75.64 & 1.451 & 3944.2 \\
\hline Very goof (did not scored) & 4.57 & 4.67 & 1 & 0.031 & 96.63 & 1.531 & 6098.4 \\
\hline \multicolumn{8}{|l|}{ Daily Living Activities } \\
\hline Did not score & -2.86 & 5.24 & 1 & 0.022 & 0.057 & 0.005 & 0.662 \\
\hline \multicolumn{8}{|l|}{ Cognition } \\
\hline Did not score & -1.15 & 1.73 & 1 & 0.188 & 0.317 & 0.057 & 1.753 \\
\hline \multicolumn{8}{|c|}{ 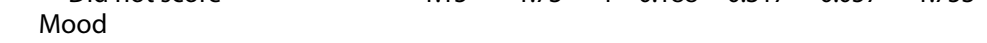 } \\
\hline Did not score & -16.16 & 0.00 & 1 & 0.994 & $9.6 \mathrm{e}-8$ & 0.000 & -- \\
\hline Scored & -12.45 & 0.00 & 1 & 0.995 & $3.9 e-6$ & 0.000 & -- \\
\hline \multicolumn{8}{|l|}{ Mobility } \\
\hline Did not score & -5.90 & 13.74 & 1 & $<0.001$ & 0.003 & 0.000 & 0.062 \\
\hline \multicolumn{8}{|l|}{ Multiple comorbidities } \\
\hline Did not score & -4.53 & 9.76 & 1 & 0.002 & 0.011 & 0.001 & 0.185 \\
\hline \multicolumn{8}{|l|}{ High risk } \\
\hline \multicolumn{8}{|l|}{ Age } \\
\hline Did not score & -5.03 & 5.18 & 1 & 0.023 & 0.007 & $8.6 e-5$ & 0.496 \\
\hline Scored & -7.02 & 7.93 & 1 & 0.005 & 0.001 & $6.7 e-6$ & 0.118 \\
\hline \multicolumn{8}{|l|}{ Self-Perception of Health } \\
\hline Scored (Poor) & 4.72 & 3.19 & 1 & 0.074 & 112.2 & 0.631 & 19955.1 \\
\hline Scored (Regular) & 4.01 & 3.18 & 1 & 0.075 & 55.23 & 0.670 & 4552.5 \\
\hline Did not Scored (Good) & 3.59 & 2.00 & 1 & 0.157 & 36.19 & 0.251 & 5216.2 \\
\hline Did not scored (Very Good) & 4.29 & 1.50 & 1 & 0.221 & 73.23 & 0.075 & 71037.1 \\
\hline
\end{tabular}

There was a considerable association between clinical-functional vulnerability and calf circumference $(p=0.066)$. Frail elderly $(48.1 \%)$ and those at risk of frailty (37\%) had decreased calf circumference, suggesting a decrease in muscle mass.

\section{DISCUSSION}

The prevalence of vulnerable elderly people found in this study is similar to that found in international studies ${ }^{(16-17)}$. However, it differs from national studies, in which the prevalence is higher ${ }^{(18-20)}$. The divergence between national findings may reflect both age - because, in this study, young elderly people predominated — and socioeconomic differences between Brazilian cities. Individuals with a higher socioeconomic level have access to health care, and may, therefore, develop healthy habits such as physical activity and, consequently, have fewer comorbidities; thus, they use a smaller amount of medication and, in turn, have better health conditions ${ }^{(21-22)}$.

The practice of physical activity had a strong influence on vulnerability ${ }^{(23-24)}$, and it is important that health professionals and managers encourage and promote this practice in the daily lives of elderly people. However, stronger actions mediated by public policies aimed at the practice of physical activity in the elderly population need and must be implemented ${ }^{(25)}$. Examples of strategies are outdoor gyms, the introduction of physical educators in health units, among others. In this context, in the city under study, there has been a Firefighter and Citizenship project for 17 years, which organizes physical activities such as dances and physical stretching in public spaces in the city ${ }^{(26)}$, actions that could be replicated in other states to strengthen practices of health promotion for the elderly population.

The comorbidities most associated with vulnerability in this study were hypertension and osteoporosis. These conditions are also positively affected by the practice of physical activity, which, in turn, generates even better health conditions for its practitioners. This reveals that this is not something linear, but a cycle in which physical activity plays a protective role with the potential to stop the development of vulnerability ${ }^{(27)}$.

Early identification of vulnerability and knowledge of associated factors helps in detecting the triggering aspects of the frailty syndrome and, thus, aids in the decision making about the functional and specific parameters of the elderly. Such actions contribute to the reduction of damage caused by poor health conditions and by external factors, such as lack of social, financial and family support ${ }^{(18)}$. 


\begin{tabular}{lcccccccc}
\hline & B & Wald & df & Sig. & Exp(B) & \multicolumn{2}{c}{ Cl95\% } \\
\hline $\begin{array}{l}\text { Daily Living Activities } \\
\quad \text { Did not score }\end{array}$ & -5.48 & 13.29 & 1 & $0.000^{*}$ & 0.004 & 0.000 & 0.080 \\
$\begin{array}{l}\text { Cognition } \\
\quad \text { Did not score }\end{array}$ & -3.16 & 6.29 & 1 & 0.012 & 0.042 & 0.004 & 0.501 \\
$\quad \begin{array}{l}\text { Mood } \\
\quad \text { Did not score }\end{array}$ & -9.68 & 37.90 & 1 & $0.000^{*}$ & $6.3 \mathrm{e}-5$ & $2.9 \mathrm{e}-6$ & 0.001 \\
$\quad \begin{array}{l}\text { Scored } \\
\text { Mobility }\end{array}$ & -3.67 & -- & 1 & -- & 0.026 & 0.026 & 0.026 \\
$\quad \begin{array}{l}\text { Did not score } \\
\text { Multiple comorbidities } \\
\quad \text { Did not score }\end{array}$ & -9.03 & 20.69 & 1 & $0.000^{*}$ & 0.000 & $2.4 \mathrm{e}-6$ & 0.006 \\
$\begin{array}{l}\text { Model adjustment: } \\
\text { Likelihood Ratio Test: }\end{array}$ & -9.28 & 26.10 & 1 & $0.000^{*}$ & $9.3 \mathrm{e}-5$ & $2.6 \mathrm{e}-6$ & 0.003 \\
$\mathrm{X}^{2}=172.3 ;$ gl = 26; $\mathrm{p}<0.001$ & Adjustment test: & & & & \\
\hline
\end{tabular}

Table 5 - Sociodemographic and clinical factors associated with clinical-functional vulnerability, regarding the risk of frailty in vulnerable elderly people treated in Primary Health Care Units, Fortaleza, Ceará, Brazil, 2019 ( $n=133$ )

\begin{tabular}{|c|c|c|c|c|}
\hline \multirow[t]{2}{*}{ Variable } & \multicolumn{3}{|c|}{$\begin{array}{c}\text { Clinical-Functional } \\
\text { Vulnerability Index - } 20\end{array}$} & \multirow[t]{2}{*}{$p$ value } \\
\hline & Robust & Frailty risk & Frail & \\
\hline $\begin{array}{l}\text { Age } \\
\qquad \begin{array}{l}60-79 \\
80-100\end{array}\end{array}$ & $\begin{array}{c}32(28.3 \%) \\
7(26.9 \%)\end{array}$ & $\begin{array}{l}42(37.2 \%) \\
15(57.7 \%)\end{array}$ & $\begin{array}{c}39(34.5 \%) \\
4(14.4 \%)\end{array}$ & 0.96 \\
\hline $\begin{array}{l}\text { Gender } \\
\text { Female } \\
\text { Male }\end{array}$ & $\begin{array}{l}27(25 \%) \\
12(38.7)\end{array}$ & $\begin{array}{l}44(40.7 \%) \\
13(41.9 \%)\end{array}$ & $\begin{array}{c}37(34.3 \%) \\
6(19.4 \%)\end{array}$ & 0.187 \\
\hline $\begin{array}{l}\text { Educational level } \\
\text { Illiterate } \\
1 \text { to } 5 \text { years } \\
\text { More than } 6 \text { years }\end{array}$ & $\begin{array}{c}5(22.7 \%) \\
17(27 \%) \\
17(31.5 \%)\end{array}$ & $\begin{array}{l}10(45.5 \%) \\
28(44.4 \%) \\
19(35.2 \%)\end{array}$ & $\begin{array}{c}7(31.8 \%) \\
18(28.6 \%) \\
18(33.3 \%)\end{array}$ & $0.008^{*}$ \\
\hline $\begin{array}{l}\text { Marital status } \\
\text { Single } \\
\text { Married } \\
\text { Stable union } \\
\text { Widow } \\
\text { Divorced }\end{array}$ & $\begin{array}{c}7(29.2 \%) \\
14(31.8 \%) \\
0 \\
12(25.5 \%) \\
6(31.6 \%)\end{array}$ & $\begin{array}{c}7(29.2 \%) \\
16(36.4 \%) \\
4(80 \%) \\
23(48.9 \%) \\
7(36.8 \%)\end{array}$ & $\begin{array}{c}10(41.7 \%) \\
14(31.8 \%) \\
1(20 \%) \\
12(25.5 \%) \\
6(31.6 \%)\end{array}$ & 0.424 \\
\hline $\begin{array}{l}\text { Skin color } \\
\text { White } \\
\text { Brown } \\
\text { Indigenous } \\
\text { Black } \\
\text { Yellow }\end{array}$ & $\begin{array}{c}4(19 \%) \\
26(31.7 \%) \\
1 \\
8(23.5 \%) \\
0\end{array}$ & $\begin{array}{c}6(28.6 \%) \\
32(39 \%) \\
1 \\
57(41 \%) \\
0\end{array}$ & $\begin{array}{c}11(52.4 \%) \\
24(29.3 \%) \\
0 \\
8(23.5 \%) \\
0\end{array}$ & 0.222 \\
\hline $\begin{array}{l}\text { Physical activity } \\
\text { Yes } \\
\text { No }\end{array}$ & $\begin{array}{c}20(40 \%) \\
19(21.3 \%)\end{array}$ & $\begin{array}{c}17(34 \%) \\
40(44.9 \%)\end{array}$ & $\begin{array}{c}13(26 \%) \\
30(33.7 \%)\end{array}$ & 0.063 \\
\hline $\begin{array}{l}\text { Comorbidities } \\
\text { Yes } \\
\text { No }\end{array}$ & $\begin{array}{c}34(26.2 \%) \\
5(55.6 \%)\end{array}$ & $\begin{array}{c}53(40.8 \%) \\
4(44.4 \%)\end{array}$ & $\begin{array}{c}43(33.1 \%) \\
0\end{array}$ & $0.020 *$ \\
\hline $\begin{array}{l}\text { Medications } \\
0-4 \\
5 \text { or more }\end{array}$ & $\begin{array}{c}33(41.8 \%) \\
6(10 \%)\end{array}$ & $\begin{array}{l}35(44.3 \%) \\
22(36.7 \%)\end{array}$ & $\begin{array}{l}11(13.9 \%) \\
32(53.3 \%)\end{array}$ & $0.001 *$ \\
\hline
\end{tabular}

It is pointed out that the poor self-perception of health is associated with moderate and high risk of frailty in the elderly; the negative perception of health is mainly associated with loss of autonomy and functional decline ${ }^{(14)}$. In this sense, it is mandatory to introduce this aspect during consultations and approaches to elderly people.

From a sociodemographic point of view, females are associated with frailty (a fact corroborated in this study), since they live longer, increasing the probability of triggering chronic and disabling conditions, which provide bodily changes that accelerate deterioration ${ }^{(31)}$.

Education has a negative impact on the functionality of the elderly, but the results found showed that education did not vary in relation to the level of frailty - this finding needs further investigation to establish a cause-and-effect relationship.

In this research, the nutritional status directly influenced the clinical-functional vulnerability at the extremes of the BMI: underweight and obese elderly. This relationship is proven by another research and is explained by changes in body composition over aging, added to the factors that lead to dependence and affect the autonomy of the elderly ${ }^{(32)}$. Thus, the use of specific anthropometric data for the elderly population should be part of the care for this population. Since it has a good correlation with morbidity and mortality indicators, it is low cost and easily applicable, the specific BMI for the elderly can be a good indicator of nutritional status, as long as professionals associate these data with the composition and distribution of the body fat ${ }^{(33)}$.

The more diseases the elderly have, the greater their chance of functional decline and frailty ${ }^{(34-35)}$. The literature reveals a strong association between functional decline and diabetes, respiratory, cardiac and osteoarticular diseases, linked to obesity, sedentary lifestyle and insulin resistance ${ }^{(36-38)}$. The presence of comorbidities leads to drug treatment, with a tendency to polypharmacy, exposing these individuals to more adverse effects, weight loss or gain, functional and cognitive impairment, frailty, and hospitalizations, which confirms the increased chance of being classified as vulnerable. The rational use of medicines by the elderly

The prevalence of frailty in vulnerable elderly in this study did not differ from national studies ${ }^{(28-29)}$. It is noteworthy that age is a major factor in the occurrence of frailty; thus, it is interesting for health professionals to plan their actions and care based on the ages of the elderly, with a more precise look with each passing year. This points to a care not only by groups, but also by stratification within this population ${ }^{(30)}$. population is a major challenge for public health. Educational and administrative measures are necessary to guarantee the geriatric population a quality pharmacotherapy ${ }^{(39)}$.

Finally, the maintenance of functional capacity has important implications for the quality of life of the elderly, since the physical limitations resulting from loss of strength, comorbidities and falls generate disabilities that influence Basic Activities of Daily 
Living (BADLs) and Instrumental Activities of Daily Life (IADLs). The greater the functional decline, the greater the weakness and the development of disabilities ${ }^{(40)}$.

\section{Study limitations}

The cross-sectional design does not allow for the establishment of a causal relationship. Also, some independent variables were self-reported, so there may be differences between actual and reported data.

\section{Contributions to the health area}

The assessment of vulnerability and frailty is necessary in Primary Health Care, as it allows stratifying, capturing, welcoming, developing actions, establishing a link between the service and the user, and thus ensuring comprehensive and continuous care for the elderly.

\section{CONCLUSIONS}

Vulnerability was associated with age, gender, education, marital status, physical activity, presence of hypertension, diabetes, osteoarthritis, osteoporosis and use of polypharmacy. In addition, it has associations with activities that demand strength. As for frailty, there was an association with low education, selfperceived health and bad mood, presence of comorbidities, use of polypharmacy, decreased mobility and calf circumference, all affecting their activities of daily living.

The perspectives are the development of longitudinal studies that can infer causal factors for frailty and vulnerability.

\section{FUNDING}

The Coordenação de Aperfeiçoamento de Pessoal de Nível Superior - CAPES (Coordination for the Improvement of Higher Education Personnel) funded this research through a master's degree scholarship.

\section{REFERENCES}

1. Witte N, De Donder L, Dury S, Buffel T, Verté D Schols J. A theoretical perspective on the conceptualisation and usefulness of frailty and vulnerability measurements in community dwelling older adults. Aporia: Nurs J. 2013;5(1):13-31. https://doi.org/10.18192/aporia.v5i1.2894

2. Fried LP, Tangen CM, Walston J, Newman AB, Hirsch C, Gottdiener J, et al. Frailty in older adults: evidence for a phenotype. J Gerontol Series A: Biol Sci Med Sci. 2001;56(3):146-57. https://doi.org/10.1093/gerona/56.3.m146

3. Jesus IT, Orlandi AA, Grazziano ES, Zazzetta MS. Frailty of the socially vulnerable elderly. Acta Paul Enferm. 2017;30(6):614-20. https://doi. org/10.1590/1982-0194201700088

4. Lourenço RA, Moreira VG, Banhato EFC, Guedes DV, Silva KCA, Delgado FEF, et al. Prevalência e fatores associados à fragilidade em uma amostra de idosos que vivem na comunidade da cidade de Juiz de Fora, Minas Gerais, Brasil: estudo FIBRA-JF. Ciênc Saúde Colet. 2019;24(1):35-44. https://doi.org/10.1590/1413-81232018241.29542016

5. Rodrigues NO, Neri AL. Vulnerabilidade social, individual e programática em idosos da comunidade: dados do estudo FIBRA, Campinas, SP, Brasil. Ciênc Saúde Colet. 2012;17:2129-39. https://doi.org/10.1590/S1413-81232012000800023

6. Neri AL, Yassuda MS, Araújo LF, Eulálio MC, Cabral BE, Siqueira MEC, et al. Metodologia e perfil sociodemográfico, cognitivo e de fragilidade de idosos comunitários de sete cidades brasileiras: Estudo FIBRA. Cad Saúde Pública. 2013;29(4):778-92. https://doi.org/10.1590/ S0102-311X2013000400015

7. Moraes S A, Soares W J S, Lustosa L P, Bilton T L, Ferrioli E, Perracini M R. Characteristics of falls in elderly persons residing in the community: a population-based study. Rev Bras Geriatr Gerontol. 2017;20(5):691-701. https://doi.org/10.1590/1981-22562017020.170080

8. Carneiro JA, Cardoso RR, Durães MS, Guedes MCA, Santos FL, Costa FM, et al. Frailty in the elderly: prevalence and associated factors. Rev Bras Enferm. 2017;70(4):747-52. https://doi.org/10.1590/0034-7167-2016-0633

9. Llano PMP, Celmira L, Sequeira CAC, Jardim VMRV J, Castro DSP, Santos F. Fatores associados à síndrome da fragilidade em idosos rurais. Rev Bras Enferm. 2019;72(2)14-21. https://doi.org/10.1590/0034-7167-2017-0079

10. Cruz DT, Vieira MT, Bastos RR, Leite ICG. Fatores associados à fragilidade em uma população de idosos da comunidade. Rev Saude Publica. 2017;51:106. https://doi.org/10.11606/s1518-8787.2017051007098

11. Fhon JRS, Rodrigues RAP, Santos JLF, Diniz MA, Santos EBD, Almeida VC, et al. Factors associated with frailty in older adults: a longitudinal study. Rev Saude Publica. 2018;26-52:74. https://doi.org/10.11606/S1518-8787.2018052000497

12. Von Elm E, Altman DG, Egger M, Pocock SJ, PC Gotzsche, Vanderbroucke J. for the STROBE Initiative. The Strengthening the Reporting of Observational Studies in Epidemiology (STROBE) statement: guidelines for reporting observational studies. J Clin Epidemiol [Internet]. 2008 [cited 2020 Jul 3];61(4):344-49. Available from: https://www.ncbi.nlm.nih.gov/pubmed/18313558

13. Bertolucci PHF, Brucki SMD, Campacci SR, Juliano Y. O Mini-Exame do Estado Mental em uma população geral: impacto da escolaridade. Arq Neuro-Psiquiatr. 1994;52(1):01-07. https://doi.org/10.1590/S0004-282X1994000100001

14. Maia FOM, Duarte YAO, Secoli SR, Santos JLF, Lebrão ML. Adaptação transcultural do Vulnerable Elders Survey-13 (VES-13): contribuindo para a identificação de idosos vulneráveis. Rev Esc Enferm USP. 2012;46:116-22. https://doi.org/10.1590/S0080-62342012000700017

15. Moraes EN, Carmo JA, Lanna FM, Azevedo RS, Machado CJ, Romero DEM. Índice de Vulnerabilidade Clínico Funcional-20 (IVCF20):reconhecimento rápido do idoso frágil. Rev Saude Publica. 2016;50:81. https://doi.org/10.1590/s1518-8787.2016050006963 
16. Saliba D, Elliott $M$, Rubenstein $L Z$, Solomon $D H$, Young RT, Kamberg $C J$, et al. The Vulnerable Elders Survey: a tool for identifying vulnerable older people in the community. J Am Geriatr Soc 2001;49(12):1691-9. https://doi.org/10.1046/j.1532-5415.2001.49281.x

17. McGee HM, O'Hanlon A, Barker M, Hickey A, Montgomery A, Conroy R, et al. Vulnerable older people in the community: relationship between the vulnerable elders survey and health service use. J Am Geriatr Soc. 2008;56(1):8-15. https://doi.org/10.1111/j.1532-5415.2007.01540.x

18. Barbosa KT, Costa KN, Pontes M, Batista PS, Oliveira FM, Fernandes MD. Aging and individual vulnerability: a panorama of older adults attended by the family health strategy. Texto Contexto Enferm. 2017;26(2):e2700015. https://doi.org/10.1590/0104-07072017002700015

19. Freitas FAS, Santos ESS, Pereira LSM, Lustosa LP. Vulnerabilidade física de idosos na alta hospitalar. Fisioter Pesqui. 2017;24(3):253-8. https://doi. org/10.1590/1809-2950/16205224032017

20. Cabral JF, Silva AMC, Mattos IE, Neves ÁQ, Luz LL, Ferreira DB, et al. Vulnerabilidade e fatores associados em idosos atendidos pela Estratégia Saúde da Família. Ciênc Saúde Colet. 2019;24(9):3227-36. https://doi.org/10.1590/1413-81232018249.22962017

21. Almeida APSC, Nunes BP, Duro SMS, Facchini LA. Socioeconomic determinants of access to health services among older adults: a systematic review. Rev Saúde Pública 2017;51:50. https://doi.org/10.1590/s1518-8787.2017051006661

22. Amendola F, Alvarenga MRM, Latorre MRDO, Oliveira MAC. Development and validation of the Family Vulnerability Index to Disability and Dependence (FVI-DD). Rev Esc Enferm USP. 2014;48(1):80-88. https://doi.org/10.1590/S0080-623420140000100010

23. Chen CY, Wu SC, Chen LJ. The prevalence of subjective frailty and factors associated with frailty in Taiwan. Arch Gerontol Geriatr. 2010;50(1):437. https://doi.org/10.1016/S0167-4943(10)70012-1

24. Berlezi EM, Gross CB, Pimentel JJ, Pagno AR, Fortes CK, Pillatt AP. Estudo do fenótipo de fragilidade em idosos residentes na comunidade. Ciênc Saúde Colet. 2019;24(11):4201-10. https://doi.org/10.1590/1413-812320182411.31072017

25. Barreto BLM, Rodrigues ICG, Silva WGO, Bezerra JCP. Public Politics facing the health of the elderly: an approach critical. EFDeportes.com, Rev Digital [Internet]. 2015 [cited 2020 Sep 20];210. Available from: https://www.efdeportes.com/efd210/politicas-publicas-voltadas-a-saude-do-idoso.htm

26. Prefeitura Municipal de Fortaleza. Projeto Saúde, Bombeiros e Sociedade [Internet]. 2020 [cited 2020 Sep 20]. Available from: https://www. bombeiros.ce.gov.br/category/projetos-sociais/projeto-saude-bombeiros-e-sociedade/

27. Camboim FEF, Nóbrega MO, Davim RMB, Camboim JCA, Nunes RMV, Oliveira SX Benefits of physical activity in the third age for the quality of life. Rev Enferm UFPE. 2017;11(6):2415-22. https://doi.org/10.5205/reuol.10827-96111-1-ED.1106201721

28. Ribeiro EG, Matozinhos FP, Guimarães GL, Couto AM, Azevedo RS, Mendoza IYQ. Self-perceived health and clinical-functional vulnerability of the elderly in Belo Horizonte/Minas Gerais. Rev Bras Enferm. 2018;71(2):860-7. https://doi.org/10.1590/0034-7167-2017-0135

29. Lins MEM, Marques APO, Leal MCC, Barros RLM. Risco de fragilidade em idosos comunitários assistidos na atenção básica de saúde e fatores associados. Saúde Debate. 2019;43(121):520-9. https://doi.org/10.1590/0103-1104201912118

30. Reis CB, Jesus RS; Oliveira e Silva CS, Pinho L. Health conditions of young and old elderly. Rev Rene. 2016;17(1):120-7. https://doi. org/10.15253/2175-6783.2016000100016

31. Rodrigues AM, Eusébio M, Santos MJ, Gouveia N, Tavares V, Coelho PS, et al. The burden and undertreatment of fragility fractures among senior women. Arch Osteop. 2018;13(1):22. https://doi.org/10.1007/s11657-018-0430-z

32. Silva JM, Dias SFL. Analysis of functional capacity and nutritional status of nursing home residents. Reon Facema [Internet]. 2017[cited 2019 Dec 20];3(4):719-26. Available from: https://www.facema.edu.br/ojs/index.php/ReOnFacema/article/view/274/165

33. Pereira IFS, Spyrides MHCA, Lára MB. Estado nutricional de idosos no Brasil: uma abordagem multinível. Cad Saúde Pública. 201;32(5). https:// doi.org/10.1590/0102-311X0017881

34. Eyigor S, Kutsal YG, Duran E, Huner B, Paker N, Durmos B, et al. Frailty prevalence and related factors in the older adult. FrailTURK Project AGE. 2015;37:50. https://doi.org/10.1007/s11357-015-9791-z

35. Santos VR, Gomes IC, Bueno DR, Christofaro DGD, Freitas JIF, Gobbo LA. Obesity, sarcopenia, sarcopenic obesity and reduced mobility in Brazilian older people aged 80 years and over. Einstein (São Paulo). 2017;15(4):435-40. https://doi.org/10.1590/1413-812320182411.31072017

36. Bandeen-Roche K, Seplaki CL, Huang J, Buta B, Kalyani RR, Varadhan R, et al. Frailty in older adults: a nationally representative profile in the United States. J Gerontol Series A: Biol Sci Med Sci. 2015;70(11):1427-34. https://doi.org/10.1093/gerona/glv133

37. Carneiro J, Ramos G, Barbosa AT, Medeiros S, Lima C, Costa F, et al. Prevalência e fatores associados à polifarmácia em idosos comunitários. Medicina (Ribeirao Preto) [Internet]. 2018 [cited 2020 Mar 15];51(4):254-6. Available from: http://www.revistas.usp.br/rmrp/article/view/154921

38. Lenardt MH, Carneiro NHK, Binotto MA, Willig MH, Lourenço TM, Albino J. Fragilidade e qualidade de vida de idosos usuários da atenção básica de saúde. Rev Bras Enferm. 2016;69(3):478-83. https://doi.org/10.1590/0034-7167.2016690309i

39. Gómez Aguirre N, Caudevilla MA, Bellostas ML, Crespo AM, Velilla MJ, Díez-Manglano J. Pluripatología, polifarmacia, complejidad terapéutica y uso adecuado de la medicación. Rev Clín Españ. 2017;217(5):289-95. https://doi.org/10.1016/j.rce.2016.12.013

40. Freitas FFQ, Soares SM. Clinical-functional vulnerability index and the dimensions of functionality in the elderly person. Rev Rene. 2019;20:e39746. https://doi.org/10.15253/2175-6783.20192039746 